\title{
The Role of Imuem Mukim in Advocating for the Prevention of Environmental Pollution in Aceh Jaya District
}

\author{
Mahdi Syahbandir ${ }^{1, *}$, Dahlawi Dahlawi², Wais Alqarni², Munawwarah \\ Munawwarah $^{3}$
}

\author{
${ }^{I}$ Faculty of Law, Universitas Syiah Kuala \\ ${ }^{2}$ Faculy of Social \& Political Sciences, Universitas Syiah Kuala \\ ${ }^{3}$ Faculty of Tarbiyah and Teaching Sciences, Universitas Islam Negeri Ar-Raniry \\ Corresponding author.Email: m.syahbandir@unsyiah.ac.id
}

\begin{abstract}
Environmental damage in Aceh Jaya is still a problem for the community to this day. Some of the problems that occur are the behavior of littering, air waste from a company to flooding problems due to damaged water culverts. In preventing these problems, it is necessary to have the role of local indigenous community leaders, namely immuem mukim. The purpose of this study was to find out how the role of the mukim in advocating the community for the prevention of environmental pollution in Aceh Jaya Regency. The research method used is a qualitative method with a case study approach. The results of the research found were the role of the mukim in solving problems at the Gampong level. Although the mukim mukim in Aceh jaya has carried out various kinds of advocacy and outreach to the community. Then regarding air pollution, regulations have also been made between the Gampong or mukim and the palm oil company. However, what the mukim does is not able to make himself a leader from a role in environmental advocacy, so he does not get support from the community and several other keuchik parties. In role theory, a person's behavior is regulated and expected by someone in a certain position. However, the immuem mukim in advocating for the community actually lacks support from the community who make rules for prohibiting waste disposal and rules for agreements to avoid waste pollution from a company that has received less attention from the community and the local Keuchik.
\end{abstract}

\section{Keywords: Role, Imuem Mukim, Environmental Pollution}

\section{INTRODUCTION}

Environmental problems are problems that are often faced by the community but still not until now. Problems can occur because of local residents themselves or those caused by companies through various kinds of waste produced by the company. According to the director of Walhi Aceh, Muhammad Nur, to reporters at a press conference at the beginning of the year, at the Walhi Aceh Office, Thursday (2/1/2020), Muhammad Nur stated that the high environmental damage that had been happening in Aceh so far was due to a lack of awareness to prevent and overcome environmental damage. from the Acehnese government. Talking about the environment can not be separated from how to manage land. In
Aceh itself there is also land that is privately owned and there is also land that is jointly owned which is managed by the local community. Due to the lack of awareness from the community, the environment becomes damaged such as garbage disposal, deforestation, and various kinds of bad deeds that result in an unfriendly environment for the community.

Based on the results of the initial observations of researchers in the Aceh Jaya environment. Researchers see various environmental problems that occur, for example, there are still many people's behavior that causes environmental damage such as littering at the Aceh Jaya Tourism area, Gunung Geurutee. Air pollution waste from PT. SA that is 
troubling residents in Aceh Jaya Regency who do not put up with the smell of the sewage. As well as the flood disaster which still left damage to the intervillage road that connected Alue Groh Village to the Ligan Pante Purba settlement, which collapsed two meters wide in Sampoiniet District. This was due to the water culverts being broken due to the impact of the flood waters.

In the culture of the local ace, the land and all its contents are viewed as the land of Tanogry/natural heritage/descendants) managed by the community for the benefit of the community. Will be done. Apart from that, there are also public interests known as Aceh's Gampong /Clan/Community Groups such as Villages and Mukim/ Public Rights/ Urayat Rights/ Old Rights/Tanoraja. Village wilderness features are only available to the local community, but people outside the village need to seek permission from the local community to cultivate the land.

One of the elements of society that plays a role in protecting the land and the environment in an area is the Mukim. Mukim itself can be interpreted as a legal community unit in the province of Nanggroe Aceh Darussalam which consists of a combination of several Gampong which have certain territorial boundaries and their own assets, domiciled directly under the Camat led by Imeum Mukim. Imeum Mukim is the Head of the Mukim Government [22]

In Qanun Number 2 of 2011 article 1 paragraph 17 which states that local wisdom is noble values that apply in the life of the community to, among other things, protect and manage the environment in a sustainable manner. Thus, the mukim is part of Aceh's local wisdom which has the authority to regulate and manage environmental conservation.

One of the strategies of Imeum mukim in protecting and managing environmental conservation is by advocating or socializing to the community to be equally aware of the importance of managing and controlling pollution and/or environmental damage together. This role is in accordance with Qanun Qanun Number 2 of 2011 CHAPTER III Article 6 which states that everyone has the right to be obligated to preserve environmental functions and control environmental pollution and/or damage [14].

It can be concluded that in addition to the government, traditional leaders, namely Imeum mukim as a form of Acehnese local wisdom, also play a role in coordinating the community in terms of preventing environmental damage. So departing from the explanation above, we are interested in conducting research related to "The Role of the Imeum Mukim in
Advocating for the Prevention of Environmental Pollution in Aceh Jaya District".

This study focuses on the role of Imuem Mukim in advocating or socializing in order to preserve the environment in Aceh Jaya District. Trying to analyze the role of Imuem Mukim in advocating the community for the prevention of environmental pollution in Aceh Jaya Regency, and seeing the perceived impact of Imuem Mukim's advocacy for the prevention of environmental pollution in Aceh Jaya Regency.

\section{THEORY}

A role is an action that is expected to enable a person to make progress-leading changes, but a leader in whether he or she can improve performance in completing assigned tasks. It is not always expected to be a benchmark for people as. May that person maximize performance in the performance of their duties.

Roles are defined by all professionals, including roles that can be interpreted as regulated behavior expected of a person in a particular position. The executives of the organization have a role, and every job brings expectations for the actions of the responsible person. The fact that the organization identifies the work it performs and the desired role behavior that accompanies it also means that role expectations are important in regulating the behavior of subordinates.

The role that researchers want to observe is the role of Imuem Mukim. The term 'mukim' itself comes from the Arabic word muqim which means a place to live [1]. Muqimun means residents who live in a place (Dictionary Council: 2002). Mukim is also a residential area led by an immuem (priest). The word imuem comes from Arabic which means "people to be followed" or leaders [1].

The duties of the Imuem Mukim are in accordance with the Qanun of Aceh Jaya Regency Number 4 of 2011 concerning the Government of Mukims, article 8 regarding the duties and functions of the Imuem Mukims, including:

1) Imuem Mukim has the task of coordinating the implementation of gampong government affairs, gampong development, community empowerment, maintaining traditional life and customs based on statutory regulations and Islamic Shari'a;

2) Has the task of coordinating the implementation of gampong government affairs, gampong development, community empowerment, 
maintaining traditional life and customs based on statutory regulations and Islamic Shari'a;

3) In carrying out the duties as referred to in paragraph (1), the Immuem Mukim has the authority to:

a. coordinating the administration of gampong administration within the local mukim;

b. supervising the implementation of the Keusyik election;

c. submits a draft mukim qanun;

d. stipulates a mukim qanun that has obtained the approval of Tuha Peut Mukim;

e. prepares and submit a draft mukim qanun concerning the Draft Mukim Revenue and Expenditure Budget (RAPBM) for discussion and approval from Tuha Peut Mukim;

f. leads the settlement of customary disputes in the local mukim;

g. gostering the mukim economy and coordinating gampong development within the local mukim;

h. the holder of the mukim financial management authority;

i. carries out other authorities in accordance with the laws and regulations;

In carrying out the authority as referred to in paragraph (2), I muem Mukim has the following functions:

a. organizes the implementation of the implementation of Islamic law, religious life, religious harmony, inter-religious communities in settlements and customary life and customs;

b. the implementation of co-administration tasks and other government affairs in the settlements that the gampong government has not yet been able to implement;

c. development coordinator to improve welfare and democratic life in a just manner;

d. development and facilitation in the fields of education, social, culture, protection of basic rights, peace and public order;

e. implementation of customary dispute resolution;

f. supervision of ecological functions and management of Natural Resources (SDA).

\section{METHODOLOGY}

The research location is a place where researchers conduct research in concurrently with phenomena or events that actually occur from the object under study in order to obtain accurate research data. In this case, it will be conducted in Aceh Jaya District. This was done because according to initial observations there were still Imeum mukim activities and various environmental problems such as air pollution, littering and flooding that damaged the environment in Aceh Jaya.

In this research method, the researcher uses a qualitative research method with a case study approach. This case study research focuses intensively on certain objects that are studied as a case [4]

So that through qualitative research with a case study approach, researchers can study intensively and can provide a broad overview of the current role of the Imeum mukim in Aceh, especially in terms of advocating for the Imeum mukim in organizing the community to care about environmental conservation.

\section{DISCUSSION}

\subsection{Customary Law-Based Forest Conservation.}

Forest management based on local wisdom is found in forest management activities, recommendations and prohibitions, as well as customary institutions. The potential for village forest development is the legal basis, support from environmental NGOs and village forest management institutions. Community perceptions and attitudes towards the implementation of the qanun and village forest in Mukim Lutueng showed strong perceptions and strong attitudes were shown by the community in three gampongs; Ganpong Mane, Lutueng and Blang Dalam. However, the people of Gampong Turue Cut show weak perceptions and attitudes. In conclusion, local wisdom is threatened by gold mining activities and illegal forest encroachment. Communities need alternative economies that do not depend on forest resources [14].

\subsection{Imuem Mukim Advocacy to the Community in Preventing Environmental Pollution}

As the researcher interviewed with Teungku Abdullah, Mukim Panga Pucok, Aceh Jaya Regency, on August 4, 2021, he said that, as Imuem Mukim had discussed with MAA regarding environmental issues including hygiene issues. He also often holds meetings 
with Mustika, in these meetings he has conveyed about environmental problems regarding irrigation. He said that the irrigation was polluted with used baby pempes, and there were also animal carcasses. Therefore, he needs awareness from each village, especially the village apparatus, namely Mr. Keuchik to bring order to its citizens. Even during the MUSRENBANG because there is room to talk, he also emphasized the same thing. only moment.

Currently he is trying to coordinate directly with Mr. Keuchik because there is financial support there.

Regarding waste in the form of air pollution from a palm oil mill, there were protests from the community and Gampong officials to the company. One of their forms of protest against the company was to make a document of the community's demands against the palm oil company in Aceh Jaya. However, after that the document from the results of last night's deliberation was not responded to at all. According to him, if the contents of the document are fulfilled, it will bring prosperity to the community, including rights assistance to orphans, the poor and environmental sustainability. He also regretted that the CSR that was expected to the community was not given to the people of Aceh Jaya, especially in Gampong Ladan Baro. Even though the land used by the palm oil company is located in Ladang Baro Village [9].

Irfan [9] added In fact, the mukim's main functions include completing the Gampong Qanun, improving the community's economy, and protecting the environment, especially the forest. Even yesterday there was a case of selling the forest, I held it because it was a community forest and there was a lot of noise with fellow Gampongs at that time and I went down there to quell the anger of the community. In addition, in various meetings $I$ have spoken about the environment for the sake of future generations to the keuchik at the sub-district office when there is a meeting. In fact, he is also the person who takes care of the village boundaries until now.

Likewise with company waste which besides air pollution there is also river pollution. This is of course dangerous, especially when there are small children who like to play in the river. It's just surprising to me that until now there has been no public protest about it. and even myself also protested about the environmental impact analysis (AMDAL) at the factory.

In my opinion, the role of the mukim is at least about maintaining the culture and customs of the Acehnese people in environmental issues, namely Kenduri Blang which is regulated by the mukim so as to minimize pests due to the simultaneous planting system. It's just that at the blang feast, it's not just eating together but also praying together, which in my opinion is the most important. So I think the mukim has played a role in protecting the environment in Aceh Jaya.

If it is related to factory waste, please note that the establishment of this PT did not involve Mukim so that the AMDAL was not in accordance with regional conditions in Aceh Jaya. That's why I think the budget given to Mukim to deal with environmental problems has not been maximized [6].

The problem of environmental pollution in Aceh Jaya was also attended by several environmental activists. There are the Forum for the Environment (WALHI) and the Indigenous Community Network (JKMA) as well as several other institutions. It's just that it's a shame that the community doesn't really respond because this will disrupt people's livelihoods. Husein [8] said, I hope that the implementation of CSR should be further optimized for Aceh Jaya, and this company should further ensure environmental preservation in Aceh Jaya.

In preserving the environment, this has not been carried out in a forum, but I convey this environmental problem through Mr. Keuchik. Where I convey about how to protect the production forest and we also anticipate the rampage of elephants. We also take care of the rare animals that are typical of Aceh Jaya which we protect [11].

\section{CONCLUSION}

Based on the above discussion, it can be emphasized that the defense of Immuem Kim in the form of a defense of environmental pollution has played a role. This role appears when Mukim can resolve the case at Mukim level after the Gampong level cannot be resolved. Imuem Mukim then campaigned for pollution control in Acejaya and disseminated information by establishing rules between Gampong or Mukim and the palm oil companies in the area. CSR was then discussed in the form of legal aid for orphans, the poor, and the sustainability of ecosystems. However, this role does not affect the community, as some people are still unresponsive and absent from keuchik hired by Imuem Mukim to stress the public.

\section{REFERENCES}

[1] Ahmad, Zakaria. 1972. Sekitar Keradjaan Atjeh Dalam Tahun 1520-1675. Medan: IKAPI

[2] Azwir, (eds). 2016. Peran Lembaga Peutua Uteun (Panglima hutan) Dalam Melestarikan 
Hutan di Pedalaman Kecamatan Geumpang Kabupaten Pidie. JESBIO 5 No. 2. (2016).

[3] Fatmawati, Endang, Preservasi, Konservasi dan Restorasi Bahan Perpustakaan, Jurnal LIBRIA. Vol. 10, No. 1. (2018).

[4] Hadari, Nawawi. Metode Penelitian Bidang Sosial, Yogyakarta: Gajah Mada University Press, 2003.

[5] Herlina, N. Permasalahan lingkungan hidup dan penegakan hukum lingkungan di Indonesia. Jurnal Ilmiah Galuh Justisi 3, No. 2, (2017).

[6] Interview with Anwar Ibrahim, Chairman of the Aceh Traditional Council of Aceh Jaya District, 5 August 2021

[7] Interview with Kamal Wijaya, Advisory Council of Ulamas of Aceh Jaya Regency, 5 August 2021

[8] Interview with M. Adan Husein, Mukim Panga Pasi, Kabupaten Aceh Jaya, 4 Agustus 2021.

[9] with M. Irfan, Keuchik Ladang Baro, Aceh Jaya District, August 4, 2021.

[10] Interview with Muhammad Ali, Secretary of Gampong Kuta Tuha, Panga District, Aceh Jaya District, 5 August 2021.

[11] Interview with Tengku Abdullah, Mukim Panga Pucok, Aceh Jaya District, August 4, 2021.

[12] Khan, M. A., \& Ghouri, A. M. Environmental pollution: its effects on life and its remedies. Researcher World: Journal of Arts, Science \& Commerce 2, No. 2, (2011).

[13] Manan, Abdul, Pencemaran dan erusakan Lingkungan dalam Perspektif Hukum Islam, Jurnal Hukum dan Peradilan 4, No. 2 (2015).

[14] Mardhiah, Ainul dkk. Pengelolaan Hutan Berbasis Kearifan Lokal Dan Pengembangan Hutan Desa Di Mukim Lutueng Kecamatan Mane Kabupaten Pidie Provinsi Aceh. Jurnal Biotik 4, No. 2. (2016).

[15] Mukhlis, M. Mukim Concept as Government's Administrator in Aceh, Jurnal Dinamika Hukum, 15, No. 2, (2015).

[16] Muslim Zainuddin, Peran dan Fungsi Kelembagaan Mukim dalam Penyelesaian Perselisihan: Analisis Praktek Hukum Adat di Aceh, Jurnal Media Syariah 19, No. 2 (2017).
[17] Sanusi, Anwar. 2014. Metodologi penelitian bisnis. Jakarta: Salemba Empat

[18] Soekanto, Soerjono. Sosiologi Suatu Pengantar, Jakarta:Rajawali, 1986.

[19] Sudiyat, Iman, Asas-Asas Hukum Adat Bekal Pengantar, Yogyakarta: liberty, 1978.

[20] Sugiyono, 2009, Metode Penelitian Kuantitatif, Kualitatif dan $R \& D$, Bandung: Alfabeta

[21] Surya, Anita. 2019. Analisis Efektivitas Pemerintahan Mukim di Kecamatan Johan Pahlawan Kabupaten Aceh Barat Provinsi Aceh. Jurnal Manajemen Pemerintahan 11, No. 1. (2019).

[22] Syahbandir, Mahdi, Sejarah Pemerintahan Imuem Mukim di Aceh, Kanun Jurnal Ilmu Hukum 16, No. 1 (2014).

[23] Taher, Alamsyah. 2009. Metode Penelitian Sosial. Banda Aceh: Syiah Kuala University Press.

[24] Tanzeh, Ahmad. 2009. Pengantar Metode Penelitian. Yogyakarta: Teras, 2009. 